\title{
Investigative Study on the Self-Perceived Level of Teachers' Professional Development Correlated with the Attitude Toward the Continuous Training in Romania
}

Horatiu Catalano, Ion Albulescu, Emanuel Sebastian Turda 


\title{
Investigative Study on the Self-Perceived Level of Teachers' Professional Development Correlated with the Attitude Toward the Continuous Training in Romania
}

\author{
Horatiu Catalano $^{\mathrm{a}^{*}}$, Ion Albulescu ${ }^{\mathrm{b}}$, Emanuel Sebastian Turda $^{\mathrm{c}}$ \\ ${ }^{a, b, c}$ Educational Sciences Department, Babes Bolyai University, Cluj-Napoca, Romania \\ *Corresponding author: horatiu.catalano@ubbcluj.ro
}

\section{Abstract}

Keywords:

Teachers,

Continuoustraining, self-evaluation,

professional training, quantitative method
Professional development throughout continuous training programs has a major role in teachers' career path. The effectiveness of these programs can be acknowledged by every teacher, as long as the aims of the programs are proper for one's professional needs. Teachers' attitude towards these programs is also very important. The study we conducted probed the opinion of a non-probability sample consisting of 118 teachers from urban and rural areas as concerns their capacity to correlate the level of professional training with the attitude toward the need for continuous training in their career.

By choosing a quantitative method, the investigation on the basis of a questionnaire was used with the intention to find out not only the ability of self-evaluation reported at the level of the training, but also the motivation, attitudes and teachers' expectations regarding the need for continuous professional development. The self-evaluation questions provided respondents' perceptions of the investigation thus, allowing us to further understand issues related to their internal nature. Therefore, sometimes these items involve difficulties in establishing the accuracy of the answers provided as regards finding a correspondence between the actual respondents' opinions and those expressed in the suitable or not so suitable answers.

\section{Zusammenfasung}

\section{Schlüsselworte:}

Lehrer Weiterbildung,

Selbstauswertung,

Professionelles

Training, Quantitaive

Methode
Professionelle Entwicklung in der kontinuierlichen Ausbildungs Programme hat eine wichtige Rolle in der Lehrer Karriere.Die Wirksamkeit dieser Programme kann geschätzt werden, indem jeder Lehrer, solange die Ziele der Programme die richtigen sind für seine/Ihre professionellen Bedürfnisse.

Die Lehrer Attitude Ihnen gegenüber ist auch sehr wichtig.In der Studie, die wir initiiert haben, wird nachgefragt nach der Meinung eines nonprobabilistischen Stichprobe, bestehend aus 118 Lehrkräfte aus städtischen und ländlichen Gebieten über Ihre Fähigkeit zu korrelieren. Die Ebene der professionellen Ausbildung mit der Haltung, die die Notwendigkeit für eine kontinuierliche Weiterbildung Ihrer Karriere garantiert.

Quantitative Methode, die wir verwendet haben. Die Untersuchung auf der Grundlage des Fragebogens, durch die wir versucht haben nicht nur die Fähigkeit zur selbst - Evaluation-berichtete auf der Ebene der Ausbildung, sondern auch die Motivationen, Einstellungen und Erwartungen auf die Notwendigkeit für die Ausbildung und auf die Entwicklung Ihrer Karriere. Die Fragen der Stellungnahme erfasst die Aspekte, die ihn seine eigene Wahrnehmung der einzelnen Teilnehmer an der Untersuchung, die Wahrnehmung, dass die Informationen über Ihre inneren Natur.

Also manchmal beinhalten diese Elemente Schwierigkeiten bei der Genauigkeit der zur Verfügung gestellten Antworten, erfuhren wir aus dem Briefwechsel die wirkliche Meinung ausgedrückt von den guten oder schlechten Antworten. Die wir erhalten haben.

\section{Introduction}

Continuous professional development refers to the training activities carried out in formal and non-formal environments, distinct in their essence, which can be ordered on an axis, depending on the distance from the requirement to solve the nonconformities and the consequences of the results of the evaluation and selfevaluation processes. Professional development, therefore, is no longer seen as something 'visited' by teachers from outside, but as something in which they actively participate, and from which they take usable skills and knowledge that have immediate currency in their classrooms (Riding 2001). It also implies setting goals centered on self-knowledge, self-assessment and the development of career planning skills, and career progression which involves monitoring the degree of accomplishment. 
Continuous training aims at updating and developing the competences of teaching staff, keeping them in line with the educational needs and the developments in the educational curriculum as well as the requirements for adapting teachers' competences to changes in education (Catalano, 2015). According to its main destinations, continuous training is aimed at:

- updating and developing, through periodic training / development programs, competencies in the field / fields of specialization corresponding to the didactic functions obtained through initial training;

- developing competences that support the evolution of one's teaching career through training and obtaining teacher training certificates;

- acquiring or developing leadership, guidance, control, evaluation in the structures and organizations of the educational system;

- acquiring new skills through retraining / requalification programs for new specializations and / or new didactic functions other than those obtained through initial training;

- acquiring complementary or extensive competencies that broaden the range of activities and functions that can be provided by the teaching staff (teaching in the E-learning system, teaching in various foreign languages, educational counseling and career orientation, adult education, etc.);

- developing and expanding transversal competences as regards social roles and personal and professional development, interaction and communication with the social and the pedagogical environment, assuming responsibilities for organizing, leading and improving the strategic performance of professional groups, selfcontrol and reflexive analysis of their own activities. (EACEA, 2019).

Professional development is expected to be an "outdoors" process in which the information needed to change behavior or growth comes from outside authorities, delivered through lectures, readings, demonstrations, and verbal advice from colleagues, supervisors, coaches or consultants (Catalano, 2016). Later on, professional development is ideally advancing to become an "in-house" process in which individuals retain responsibility for directing their own growth and continuous improvement by continually studying best practices and personal goals in collaboration with colleagues (Sheridan, Edwards, Marvin \& Knoche, 2009).
Professional career represents the professional evolution of an individual throughout his life. Within the same profession, a person's career may be subject to specializations, refinements or professional promotions. Career can also be viewed from an economic, sociological or psychological point of view:

- from an economic point of view, the career is a succession of professional positions occupied by a person, as a result of his training and professional merits; - from a sociological point of view, it represents a succession of roles played by a person, each of them underlying the next;

- from the psychological point of view, the choice of roles and the success of their endeavor depend on the aptitudes, interests, values, needs, previous experience and aspirations of the person concerned (Pitariu, 2000).

The teaching career can be approached from two different perspectives. One that has an internal nature and is focused on the individual's interpretation of objective experiences through his subjectivity, which involves a series of stages of training, modeling, development, refining of attitudes and skills and promotion of values specific to the profession. The second dimension of the definition of the teaching career has an external nature and involves a succession of positions or functions over time, in a gradual manner, in accordance with certain legal provisions: debutant teachers, definitive teachers, teachers who have second degree and teachers who have first degree.

The teaching career can be structured and organized in a number of different ways, and for a number of different reasons. While most continuous training experiences might be considered as means of introducing or enhancing knowledge, skills and attitudes, it cannot be assumed that this is uncontested (Kennedy 2005). Eraut (1994) argues that it is not merely the type of professional knowledge being acquired that is important, but the context through which it is acquired and subsequently used that actually helps us to understand the nature of that knowledge. Analyzing the means through which continuous training for teachers is organized and structured may help us to understand not only the motivation behind such structures, but also the nature of professional knowledge and professionalism itself. 
In order to reveal the importance of professional development, Bruce Joyce and Beverley Showers (2002) promoted the following ideas:

- In addition to the development of knowledge, skills and effective implementation, professional training should allow people to learn how to be more effective learners.

- Training consists of four main components: developing knowledge, through exploring theory to understand the concepts behind a skill or strategy; the demonstration or modelling of a skill; the practice of a skill and peer coaching.

- The more complex the desired outcomes and the greater the degree of transfer required, the more necessary it will be to use all four training components; however, a multifaceted design is necessary whatever the desired outcome.

- In order for the teachers to become effective learners, they need specific attitudes and skills, including persistence, understanding of the transfer of training, understanding of the need for theory and the ability to use peers productively.

- Peer coaching not only contributes to the transfer of training; it also facilitates the development of new school norms of collegiality and experimentation.

- The primary activity of peer coaching is collaborative planning and development.

- Feedback can become evaluative and supervisory and training for effective feedback can be time consuming.

Teacher development occurs when these aspects of development are occurring: personal, professional and social development. This is because teacher development is a learning process, so emotions give a direction on how the brain functions; positive emotions (like motivation) boost engagement in learning.

The various definitions of professional development found in the literature imply an ongoing process of developing opportunities or activities for the improvement of teacher qualifications. The qualifications relate specifically to knowledge in the teacher's content area. Also, there is an expectation that a relationship exists between a teacher's professional development and the teacher's practice in the classroom (Meagher, 2011).

Burchell, Dyson, and Rees (2002) sustain the importance of teaching staff development in order to promote school improvement. Reynolds, Bollen, Creemers, Hopkins, Stoll, and Lagerweij (1996) and
West-Burnham and O'Sullivan (1998) remind us that for a school's development plan to have an impact on pupil achievement, the link between the development strategies, and modifications in curriculum or teaching needs to be in place.

Concerning the needs for professional development activities, Badri \& al. (2016) state that teachers learn best through professional development that addresses their needs (Meissel, Parr, and Timperley, 2016). The theoretical framework of adult learning theory shares the need for ongoing quality professional development, which requires teachers to become lifelong adult learners (Villegas-Reimers 2003; Hiebert, Gallimore, and Stigler 2002). Professional development needs include many different activities. Some activities focus on students with special needs and managing the classroom.

What should good training be trying to accomplish? The authors start from the premise that training needs to enable people to learn new knowledge and skills and to transfer these into their practice. Of equal importance, they suggest, is the need for training to help people to learn how to become more effective learners. The way to do this is to identify the outcomes which the training is intended to achieve and to select those training components (knowledge and theory, modelling, practice and peer coaching) most likely to succeed in achieving them). The range of possible targeted outcomes they identify are: knowledge or awareness of educational theories and practices, new curricula or academic content, positive attitude changes, for example towards their own role, different groups of children and aspects of the curriculum, the development of skills, for example in designing and delivering questions, transfer of training and 'executive control' - generating consistent and appropriate use of the new skills and strategies in classroom practice. This, the authors stress, is the critical point at which staff development impacts on student achievement. The authors show how some outcomes are easier to achieve than others because they are closer to teachers' existing practice. The newer they are, the harder to achieve. Similarly, some outcomes are more complex than others. Trainers need to be able to gauge the difficulty level to help plan the intensity and duration of training and select the components they will use accordingly (Bruce and Beverley 2002).

Being motivated to choose a teaching career and being motivated to remain in the teaching profession are 
important issues on which many researches have been done, as reality shows that more and more teachers are considering a career change.

In the attempt to meet the teachers' professional development needs, decision-makers and practitioners need to consider both how to support and encourage participation, and how to ensure that opportunities match the needs perceived by the teaching staff (OECD, 2009).

\section{Research methodology}

Our interest in pursuing this line of research is also, in part, a reaction to the way in which issues of implementation of the vocational educational and training reforms seemed to be commonly reduced to instrumental problems concerning the role of teachers in the process. Teachers are positioned as not having the necessary knowledge and skills to meet this new situation. They therefore require professional development in order to implement change.

In Romania, continuous training is a right that is achieved through training and professional conversion, and the career development of the teaching staff in preuniversity education is achieved by passing the final exams and obtaining the second and first didactic degrees.

Granting second degree in teaching means the acquisition by the teacher of a plus of professionalization, confirmed by the results obtained with evidence specifically designed to highlight added value acquired in the period since the completion of the studies.

In the study we initiated, we surveyed the opinion of a non-probability sample (sample of convenience) consisting of 118 pre-university teachers with a basic function in urban and rural schools compared to their ability to correlate the level of professional training with the attitude towards the need for continuous training specific to the development of the teaching career. The sample consisted of teaching staff who passed the exam for obtaining the second didactic degree.

The aim of this study was to identify the relevant factors that influence the development and progress in the teaching career. The hypothesis of the study is the following: a positive attitude towards continuous development of the teaching staff correlates significantly with their ability of self-appraisal which contributes to the formation of an adequate perception of professional development.

The quantitative method we used was the survey based on a questionnaire through which we attempted to capture not only the self-appraisal capacity related to the professional training but also their motivations, attitudes and expectations towards the need for development in the teaching career, and the processing and interpretation of data was accomplished through the SPSS program, one of the most used in statistical data analysis.

In terms of practical approach, certain relationships can only be studied through correlational design, as is our study by which we correlated two variables using a questionnaire. Due to ecological validity, the relationship identified in the correlation study can be used more effectively in prediction of behaviors than the one identified through the experiment. The advantage of such an approach is that the scores on both variables reflect a multitude or a range of variables that the subject has already experienced.

In order to determine whether there is a relationship between the attitude towards the continuous development of the teaching staff and their ability of self-appraisal, we have made a correlation between the two variables using the Pearson (r) linear correlation coefficient. The closer $r$ is to one of the extreme values ( -1 or 1$)$, the stronger the link between the two variables. The result is presented in the table below: 
Table 1. The matrix of correlations between the attitude towards the continuous development of the teaching staff and their ability of self-appraisal

\begin{tabular}{lllll}
\hline Variables & Mean & $\mathbf{1}$ & $\mathbf{2}$ & $\mathbf{R}^{2}$ \\
(SD) & & & \\
$\begin{array}{l}\text { 1. The attitude towards the } \\
\text { continuous training of the } \\
\text { teachers }\end{array}$ & 36.69 & - & & .14 \\
$\begin{array}{l}\text { 2. Capacity of self- } \\
\text { appraisal of teachers }\end{array}$ & 20.02 & $.38^{*}$ & - & \\
& $(2.47)$ & & & \\
\hline
\end{tabular}

There is a significant positive correlation between the attitude towards the continuous development of the teaching staff and their ability of self-appraisal $\left(\mathrm{r}_{(116)}=\right.$ $0.38, \mathrm{p}<0.01)$. As $r$ represents an expression of the effect size, referring to Cohen's criteria (1998), turns out that relationship between attitudes towards the continuous training of the teachers and their capacity of self-appraisal is a moderate one. Calculating the coefficient of determination $\mathrm{R}^{2}$ we obtained a $\mathrm{R}^{2}=.14$ that means $14 \%$ of the variance of the attitude towards the continous training is explained by the teachers' self-appraisal capacity.

Table 2 shows the minimum and maximum scores, the averages and the standard deviation of the two correlated variables.

Table 2. Scores, averages and standard deviation of the variables

\begin{tabular}{lrrrrr}
\hline & $\mathbf{N}$ & Min. & Max. & M & AS \\
\hline $\begin{array}{l}\text { 1. The attitude towards the continuous } \\
\text { training of the teachers }\end{array}$ & 118 & 28 & 44 & 36,69 & 3,9 \\
$\begin{array}{l}\text { 2. Capacity of self-appraisal of teachers } \\
\text { 118 }\end{array}$ & & & & & 0 \\
& & & & & 70,02 \\
\hline
\end{tabular}

In our study, the measurement of the standard deviation directly targets the estimation of the population deviation to which the sample belongs.

To determine the degree of homogeneity of the sample, we calculated the coefficient of variability $\mathrm{V}$ obtained by reporting the standard deviation to the sample average.

- $\mathrm{S}$ is the standard deviation: 6.37

- $\mathrm{M}$ is the average: 56.71

$$
\text { - } \mathrm{V}=(6.37 / 56.71) * 100=11.23 \%
$$

The interpretation of the variability coefficient is based on the values obtained: if the value of the coefficient is between 0 and $15 \%$, as in our case, the average is representative because the measured sample is homogeneous.

Frequency distribution to the item $<$ I am pleased with the progress I have made so far in terms of my earnings.> from the scale for assessing the teachers' self-appraisal is 
set out in chart no. 1 . Thus, most of the respondents (36\%) are not very sure of the progress they have made in terms of revenue, and $8 \%$ of the participants in the investigation are satisfied with the material progress and $7 \%$ are totally disagreeable with the progress made. There is an almost equal score between those who are totally in agreement with the material progress and those who are totally disagreeable. These scores can be attributed to the fact that up to this level of careers, financial motivation is not in line with the cognitive effort and time that teachers reserve for the preparation and support of specific teaching-learning activities (see Figure 1).

\section{Figure 1. First item scores}

I am pleased with the progress I have made so far in terms of my earnings.

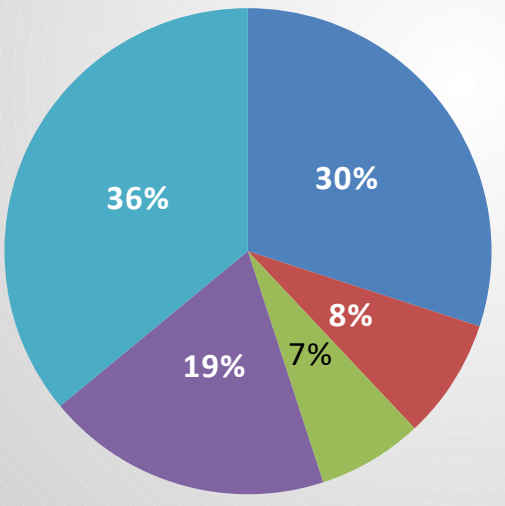

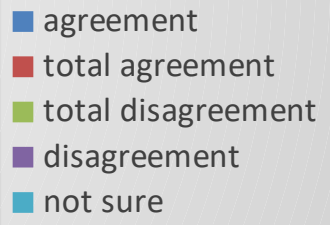

The distribution of the frequency to the scale item for evaluating teachers' self-appraisal capacity, related to the perception of the respondents concerning the obtaining of the second didactic degree and its consideration as a determinant for the professional development is set out in figure 2, which shows that $81 \%$ of the teachers participating in the research consider that obtaining the second didactic degree is a priority factor in the professional development.

Figure 2. Second item scores

Obtaining the second didactic degree is a priority factor in my professional development.

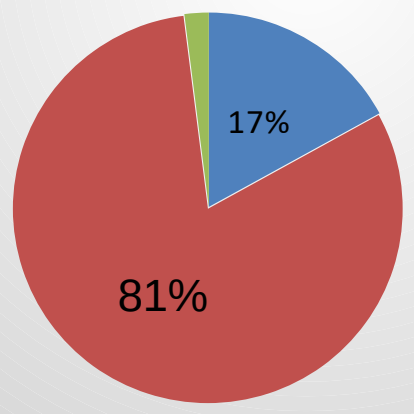

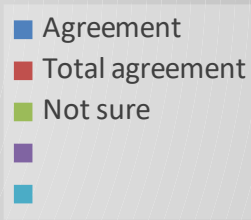

Total agreement

Not sure

口
Figure 3 shows the results obtained from the scale item for assessing attitudes towards continuous development of the teaching staff, which measured the frequency with which they collected information about employers or the opportunities to get a job other than the one in the education system. We observe the obvious conservative tendency in most of the respondents, $64 \%$ who showed very little or occasionally the tendency to look for another job outside the education system and a clear attempt to 
change their teaching career is attributed to a percentage of $9 \%$ of respondents.

Figure 3. Third item scores

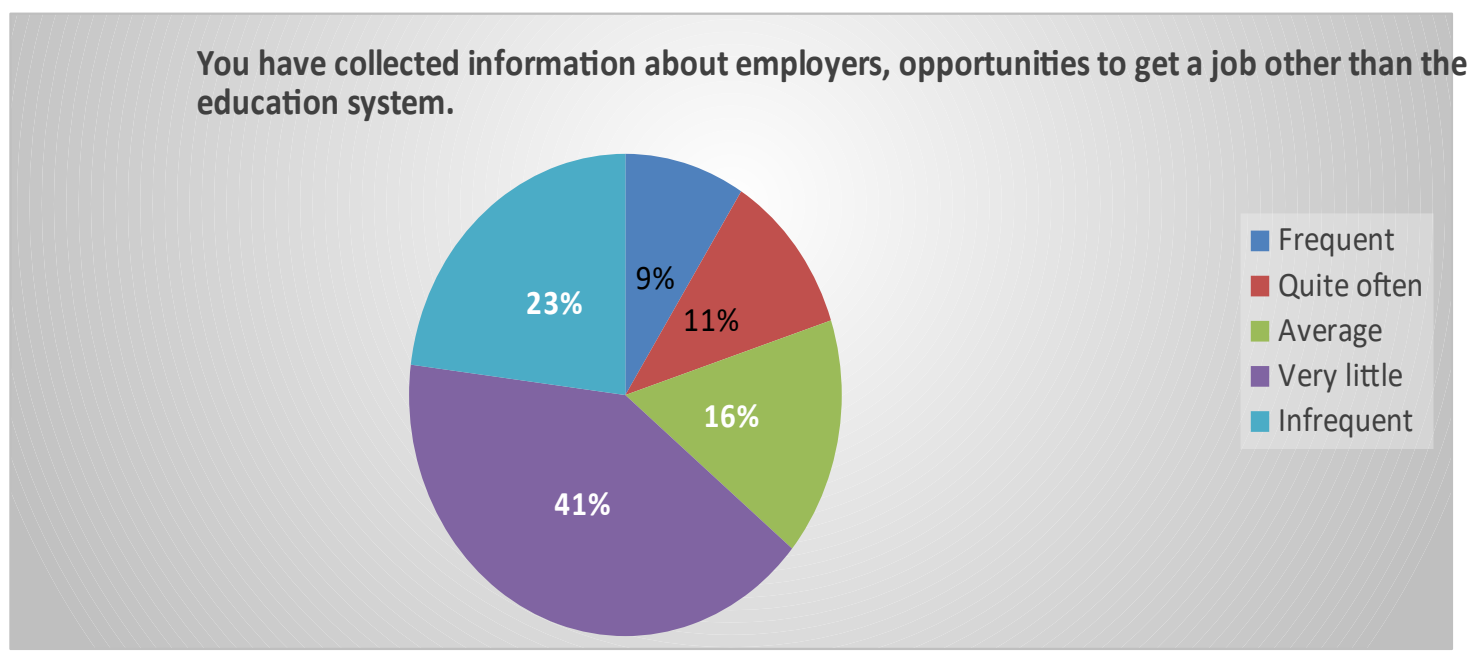

being

followed

by a

salary

increase.

Tables 3, 4, and 5 show the perception that respondents have on the correlation between obtaining the second didactic degree and the three types of variables with which this type of progress in the teaching career is associated. The most obvious correlation is with the variable economic implications, i.e. the obtaining of the second didactic degree is perceived by $64 \%$ of the respondents as
Variable professional development is perceived in the second position as the correlation level with the didactic degree and the third variable, the cognitive development has a modest degree of correlation with the first two variables. Consequently, for only $8 \%$ of the respondents the research correlates with the first variable in the perception attributed to the three listed variables.

\begin{tabular}{rrrrrr}
\hline & Frequency & Percent & $\begin{array}{r}\text { Valid } \\
\text { percent }\end{array}$ & $\begin{array}{r}\text { Cumulative } \\
\text { percent }\end{array}$ \\
\hline Valid & 1st & 64 & 54.2 & 54.2 & 54.2 \\
& 2nd & 18 & 15.3 & 15.3 & 69.5 \\
& 3rd & 6 & 5.1 & 5.1 & 74.6 \\
& Thth & 30 & 25.4 & 25.4 & 100.0 \\
& Total & 118 & 100.0 & 100.0 & \\
\hline
\end{tabular}

Tabel 3. Economic implications 


\begin{tabular}{crrrrr}
\hline & \multicolumn{2}{c}{ Frequency } & Percent & $\begin{array}{r}\text { Valid } \\
\text { percent }\end{array}$ & $\begin{array}{r}\text { Cumulative } \\
\text { percent }\end{array}$ \\
\hline Valid & 1st & 44 & 37.3 & 37.3 & 37.3 \\
& 2nd & 58 & 49.2 & 49.2 & 86.4 \\
& 3rd & 8 & 6.8 & 6.8 & 93.2 \\
& 4th & 4 & 3.4 & 3.4 & 96.6 \\
& 5th & 4 & 3.4 & 3.4 & 100.0 \\
& Total & $\mathbf{1 1 8}$ & $\mathbf{1 0 0 . 0}$ & $\mathbf{1 0 0 . 0}$ & \\
\hline
\end{tabular}

\begin{tabular}{rrrcrr}
\hline & Frequency & Percent & $\begin{array}{r}\text { Valid } \\
\text { percent }\end{array}$ & $\begin{array}{r}\text { Cumulative } \\
\text { percent }\end{array}$ \\
\hline Valid & 1st & 8 & 6.8 & 6.8 & 6.8 \\
& 2nd & 26 & 22.0 & 22.0 & 28.8 \\
& 3rd & 26 & 22.0 & 22.0 & 50.8 \\
& 4th & 54 & 45.8 & 45.8 & 96.6 \\
& 5th & 4 & 3.4 & 3.4 & 100.0 \\
& & 118 & 100.0 & 100.0 & \\
\hline
\end{tabular}

\section{Table 5. Cognitive development}

\section{Study boundaries}

The questionnaire survey method reveals through questions of opinion aspects pertaining to the perception of each participant in the investigation, a relative perception of their inner universe, mood, and sometimes these items imply difficulties in the accuracy of the answers given, the consistency between real views and those expressed by suitable or unsuitable, true or false answers.

We believe that the limited sample of teachers we used in this research, compared to the large number of preuniversity teachers, could be another limit of our investigation.
The results of the survey based on the questionnaire show that the majority of the investigated teachers correlate positively the achievement of the second didactic degree with the development in the didactic career, and the attitude towards the continuous training and their capacity for self-appreciation positively influences the perception regarding the professional and personal development, seen as a personal growth through the accumulation of cognitive and motivational experiences.

The respondents' answers allow us to confirm that Blended Learning programs can improve adult education generally and particularly it can contribute to the increase of efficiency and the visibility of continuing educative programs made for teachers by establishing of new, Blended Learning based methods.

\section{Discussion and conclusions}


Although at European level there are concerns about the professional development of teachers, many studies that have been developed proved that it is difficult to identify their pragmatic effects. Djoub (2018) interprets teacher identity in a holistic fashion and goes beyond focusing only on the professional aspects of being a teacher. The author maintains the integrity between the intellectual, emotional and spiritual aspects of teacher identity that can lead to a "new wholeness" Palmer (1998). According to him, this wholeness does not mean perfection, rather "it means becoming more real by acknowledging the whole of who I am (Palmer 1998, 13). Research has therefore attempted to explore the relationships between teacher identity and several related components that contribute to its development, e.g., teacher knowledge, professional development, language learning, and the role of emotions. To explore the personal or invisible side of teacher's identity, teacher knowledge, beliefs and emotions are to be accounted for.

Professional development is positively correlated with personal development when the individual needs, objectives and exigencies are linked to the educational policies promoted by the state authorities. Therefore, in the didactic profession, the motivation of the person, the intrinsic motivation, dependent on the personal desire and the beliefs of self-efficacy, are in a relationship of interdependence.

There are a range of life skills that assist teachers in coping with the challenges of everyday living. Getting organized, solving problems, engaging and caring about students are among the key life skills that teachers need in the profession.

Regarding the findings, we have also identified similarities with other studies. Therefore, Kramarski and Michalsky (2009) propose that such programs should focus on the three key elements found here to influence teachers' professional growth: empowering teachers' skills, strengthening their pedagogical knowledge, and shifting teachers' perceptions to a student-centered approach toward learning and teaching.

The didactic career is double-dimensional, on the one hand the objective side which implies the development and progress of the teaching staff and, on the other hand, the subjective side which represents the proper professional path, consisting of the assumption of a very complex ensemble of knowledge, skills, aspirations and individual motivations, relative to the requirements of the education system.

It is very important to be aware of the fact that personal development is a powerful tool to reach a well-defined and healthy sense of self as teachers (self-concept enhancement), which can result in positive self-esteem and self-confidence. Besides, it enables teachers to recognize, understand and manage their emotions thereby having good intrapersonal skills (emotional intelligence).

\section{Authors note:}

Horatiu Catalano is Associate Professor at the Faculty of Psychology and Sciences of Education (BabeşBolyai University, Cluj Napoca, Romania) in the Department of Educational Sciences. His research and teaching areas are focused on Early Childhood Education, Teaching Process, Pedagogy of Play, Continuous Professional Development etc. During his professional career, he published an important number of studies in national and international volumes. He coordinated a series of volumes concerning teachers' professional development, educational alternatives and |pedagogy of play.

Ion Albulescu is University habilitated Professor and Ph.D. Coordinator at the Faculty of Psychology and Sciences of Education (Babeş-Bolyai University, ClujNapoca, Romania) Department of Educational Sciences, Faculty of Psychology and Educational Sciences. His research interest is reflected in a series of studies, articles and books published by prestigious international and national editors. The Professor Albulescu teaching and research area covers several educational domains such as Educational Alternatives, Comparative Education, Pedagogical Theories and History of Educational Thinking etc.

Emanuel Sebastian Turda is PhD. student at Doctoral School "Education, Reflection, Development", Faculty of Psychology and Educational Sciences from Babeş-Bolyai University, Cluj-Napoca, Romania. His research areas are oriented towards career counseling and developing the vocational identity among adolescents.

\section{References}


Catalano, H. (2016), Professional Development and Progression in Educational Career - Ascertaining Study, The European Proceedings of Social \& Behavioural Sciences, published by Medimond Monduzzi Proceedings Divison, Editori: Antonio Sandu, Ana Frunză, Gabriel Gorghiu, Emilian Ciongaru, 8589.

Badri, M., Alnuaimi, A., Mohaidat, J., Yang, G., Rashedi, A.Al. (2016). Perception of Teachers' Professional Development Needs, Impacts, and Barriers: The Abu Dhabi Case. SAGE Open. https://doi.org/10.1177/2158244016662901.

Bruce, J., Beverley, S. (2002). Designing Training and Peer Coaching: Our needs for learning. VA. USA. ASCD.

Burchell, H., Dyson, J., Rees, M. (2002). Making a difference: a study of the impact of continuing professional development on professional practice. Journal of In-Service Education. 28:2. 219-230. DOI: 10.1080/13674580200200180.

Catalano, H. (2015). Pedagogical implications of using net support school application in teaching educational sciences. In: Proceedings of the $10^{\text {th }}$ International Conference on Virtual Learning. Bucharest University Press.

Catalano, H. (2016), Professional Development and Progression in Educational Career - Ascertaining Study, The European Proceedings of Social \& Behavioural Sciences, published by Medimond Monduzzi Proceedings Divison, Editori: Antonio Sandu, Ana Frunză, Gabriel Gorghiu, Emilian Ciongaru, 8589.

Djoub, Z. (2018). Exploring Teachers' Identity: Reflections and Implications. Arab World English Journal, 9 (1). DOI: https://dx.doi.org/10.24093/awej/vol9no1.8.

EACEA. (2019). Continous professional development of teachers from early childhood and pre-university education". https://eacea.ec.europa.eu/nationalpolicies/eurydice/content/continuingprofessional-development-teachers-working-early-childhood-and-schooleducation-61_ro./ [Accessed 13 May2019].

Eraut, M. (1994). Developing Professional Knowledge and Competence. London: Falmer Press.

Hiebert, J., Gallimore, R., and J. W. Stigler. (2002). A Knowledge Base for the Teaching Profession: What Would It Look Like and How Can We Get One?. Educational Researcher, 31(5), 3-15. https://doi.org/10.3102/0013189X031005003
Kennedy, A. (2005). Models of Continuing Professional Development: a framework for analysis. Journal of In-Service Education. 31:2, 235-250, DOI: 10.1080/13674580500200277.

Kramarski, B., Michalsky, T. (2009). Investigating preservice teachers' professional growth in self-regulated learning environments. Journal of Educational Psychology. 101(1). 161-175. http://dx.doi.org/10.1037/a0013101.

Meagher, T. (2011). An Investigation of the Relationships of Teacher Professional Development Teacher Job Satisfaction, and Teacher Working Conditions. $\mathrm{PhD}$ diss. Loyola University Chicago.

Meissel, K., Parr, J., Timperley, H. (2016). Can professional development of teachers reduce disparity in student achievement?. Teaching and Teacher Education. 58. 163-173. DOI: 10.1016/j.tate.2016.05.013.

Palmer, P. J. (1998). The courage to teach: Exploring the inner landscape of a teacher's life. San Francisco: Jossey-Bass Publishers.

Pitariu, H. (2000). Managementul resurselor umane: Măsurarea performanțelor profesionale [Human Resources Management: Evaluation of Professional Performance]. Bucharest: ALL BECK Publishing House.

Reynolds, D., Bollen, R., Creemers, B., Hopkins, D., Stoll, L., Lagerweij. N. (1996). Making Good Schools: linking school effectiveness and school improvement. London: Routledge.

Riding, P. (2001). Online teacher communities and continuing professional development". Teacher Development. https://doi.org/10.1080/13664530100200144.

Sheridan, S.M., Edwards, C.P., Marvin, C.A., Knoche, L. (2009). Professional Development in Early Childhood Programs: Process Issues and Research Needs. Early Education and Development. 20: 3, 377-401, https://doi.org/10.1080/10409280802582795.

Villegas-Reimers, E. (2003). Teacher professional development: An international review of the literature. Paris. France: UNESCO: International Institute for Education Planning. http:// unesdoc.unesco.org/images/0013/001330/133010e.pdf

West-Burnham, J., O'Sullivan, F. (1998). Leadership and Professional Development in Schools. London: Financial Times Management. 